\begin{abstract}
WE estimated the serum levels of IL- 6 , TNF- $\alpha$ and IL10 , and generation of superoxide radicals, as well as their mutual dependence, in 63 SLE patients at various stages of disease activity. Our results indicate a statistically significant increase of the serum levels studied, and an increase of superoxide anion generation by granulocytes, in correlation with SLE activity. These results indicate that oxygen metabolism and the examined cytokines play an important role in pathogenesis of SLE. The assessment of these parameters can be useful in the estimation of disease activity.
\end{abstract}

Key words: Systemic lupus erythematosus activity, Interleukin 10, Interleukin 6 , Tumor necrosis factor- $\alpha$, Generation $\mathrm{O}_{2}$

\section{Estimation of SLE activity based on the serum level of chosen cytokines and superoxide radical generation}

\author{
Elzbieta Waszczykowska, Ewa Robak, \\ Anna Wozniacka, Joanna Narbutt, \\ Jolanta Dorota Torzecka and \\ Anna Sysa-Jedrzejowsk $a^{\text {CA }}$
}

Department of Dermatology and Venereology, Medical University of Lodz, Krzemieniecka 5, 94-017 Lodz, Poland

\author{
${ }^{\mathrm{CA}}$ Corresponding Author \\ Tel/Fax: +(48) 426884565 \\ Email: sjedrzej@ck-sg.p.lodz.pl
}

\section{Introduction}

Systemic lupus erythematosus (SLE) is a multisystem disease that is caused by tissue damage resulting from antibody and complement-fixing immune complex deposition. Inflammatory responses triggered by local formation and deposition of antigen-antibody immune complexes are responsible for the clinical manifestations of vasculitis and involvement of internal organs. Inflammation in systemic lupus erythematosus, mediated by a complex interaction of the cellular and humoral components of the immune response, plays an important role. For years SLE has been considered as a disease caused by $B$ cell hyperactivity and concomitant $\mathrm{T}$ cell hyperactivity. ${ }^{1}$ However, currently many authors claim that SLE is a T cell-dependent disease. ${ }^{2}$

In order to explain the mechanisms responsible for immune regulation in SLE, cytokines have become the object of intensive studies. ${ }^{3,4}$ These proteins may affect different cells and are also involved in immunity processes and inflammatory responses. Some data show that interleukin-6 (IL-6) and tumor necrosis factor- $\alpha$ (TNF- $\alpha)$ play an important role in the pathogenesis of SLE. ${ }^{5}$

According to some studies, interleukin-10 (IL-10) plays a superior role over IL-6 and TNF- $\alpha$ in some autoimmunological and inflammatory diseases, including SLE. ${ }^{6-8}$ Interleukin-10 is a pleiotropic cytokine produced mainly by lymphocytes $T$ and $B$, monocytes and mastocytes. It exerts multidirectional influence on the processes of immunological response and inhibits the production of IFN- $\gamma$ by lymphocytes T, and IL-6, IL- 1 and TNF- $\alpha$ by macrophages. It also suppresses the production of active oxygen forms by activated macrophages, and stimulates the proliferation and differentiation of lymphocytes $B$ and the synthesis of immunoglobulins by these cells, in particular in the presence of IL-4. The literature on the role of IL-10 in the development of SLE is scarce and controversial. ${ }^{6}$

In recent years active oxygen forms produced in the processes of biological oxygenation and reduction have raised the interest of researchers. ${ }^{9}$ Spontaneous non-controlled reactions which give excessive amounts of active oxygen forms, and cause defects of protective enzymes, may be one of the pathogenic elements in the diseases of inflammatory background, like SLE. ${ }^{10,11}$ The most common reactive oxygen forms in the human organism are: superoxide anion radical $\left(\mathrm{O}_{2}{ }^{-}\right)$, hydroxyl radical $(\mathrm{OH})$, hydrogen peroxide $\left(\mathrm{H}_{2} \mathrm{O}_{2}\right)$, nitrogen oxide (NO) and others.

The mechanism of destruction of cells and tissues caused by superoxide radicals is based on both direct toxic influence on the cells and indirect effect via the production of other biologically active compounds. $^{12}$

The goal of our study was to estimate the serum levels of IL-6, TNF- $\alpha$, IL-10 and superoxide anion radicals in patients suffering from SLE. In this study we tried to find the correlation between the serum levels of these parameters and the disease activity. 
Table 1. Clinical data

\begin{tabular}{|c|c|c|c|c|c|c|c|c|c|c|}
\hline \multirow{2}{*}{$\begin{array}{l}\text { Studied group } \\
\text { Sex }\end{array}$} & \multicolumn{2}{|c|}{ Group I } & \multicolumn{2}{|c|}{ Group II } & \multicolumn{2}{|c|}{ Group III } & \multicolumn{2}{|c|}{ Group IV } & \multicolumn{2}{|c|}{ Control group } \\
\hline & $\mathrm{F}$ & $\mathrm{M}$ & $F$ & M & $\mathrm{F}$ & M & $\mathrm{F}$ & M & $F$ & $\mathrm{M}$ \\
\hline $\begin{array}{l}\text { Number of } \\
\text { patients }\end{array}$ & 20 & 1 & 11 & 0 & 21 & 3 & 7 & 0 & 15 & 1 \\
\hline Age (years) & $20-60$ & 16 & $24-59$ & - & $26-61$ & $38-60$ & $31-55$ & - & $16-60$ & 45 \\
\hline $\begin{array}{l}\text { Duration of } \\
\text { the disease }\end{array}$ & $\begin{array}{l}3 \text { months } \\
-5 \text { years }\end{array}$ & 5 months & $\begin{array}{l}3 \text { months } \\
-3 \text { years }\end{array}$ & - & $\begin{array}{l}1-10 \\
\text { years }\end{array}$ & $\begin{array}{c}2-8 \\
\text { years }\end{array}$ & $\begin{array}{l}4-15 \\
\text { years }\end{array}$ & - & - & - \\
\hline $\begin{array}{l}\text { Treatment } \\
\text { (mg per day) }\end{array}$ & $\begin{array}{c}\text { Not } \\
\text { treated }\end{array}$ & $\begin{array}{l}\text { Not } \\
\text { treated }\end{array}$ & $\begin{array}{l}\text { P } 40-60 \\
\text { or } \\
\text { D } 8-12\end{array}$ & $\begin{array}{l}\text { P } 40-60 \\
\text { or } \\
\text { D } 8-12\end{array}$ & $\begin{array}{c}\text { P } 10-20 \\
\text { and/or } \\
\text { A } 50-100\end{array}$ & $\begin{array}{c}\text { P } 10-20 \\
\text { and/or } \\
\text { A } 50-100\end{array}$ & $\begin{array}{l}\text { Not } \\
\text { treated }\end{array}$ & - & $\begin{array}{l}\text { Not } \\
\text { treated }\end{array}$ & $\begin{array}{l}\text { Not } \\
\text { treated }\end{array}$ \\
\hline SLAM scale & $>10$ & $>10$ & $>10$ & $>10$ & $<10$ & $<10$ & $<6$ & - & - & - \\
\hline
\end{tabular}

$D$, dexamethasone; $P$, prednisone; $A$, azathioprine

\section{Patients and Methods}

The study comprised 63 patients with SLE (60 women and three men) aged between 12 and 60 years. The diagnosis was based on the presence of at least four out of 11 diagnostic criteria established by the American Rheumatological Association. The duration of the disease was from 4 months to 24 years. During our study 51 patients were treated with glycocorticosteroids, and five with glycocorticosteroids in combination with azathioprine (Table 1 ). In all patients the activity of the disease was determined according to the SLAM (systemic lupus activity measure) scale, as described by Liang et al. ${ }^{13}$ It lists 33 clinical and laboratory manifestations of SLE. Each of them is assessed as either active or inactive. Possible scores with this scale vary from 0 to 86 points.

The active stage of the disease (over 10 points) was found in 32 patients, including 21 not treated with immunosuppression. The remaining were in clinical remission, among whom seven were not treated and 24 were treated with low, maintenance doses of immunosuppressive drugs (Table 2). The control group constituted 16 normal individuals, matched for sex and age.

\section{Laboratory tests}

On the day of blood sampling for IL-6, TNF- $\alpha$, IL-10 and the following laboratory parameters were analysed: complete blood cell count (CBC), erythrocyte sedimentation rate (ESR), blood urea nitrogen and creatinine level, fibrinogen level, partial thromboplastin time (PTT), immunoglobulins (IgG, IgA, IgM) and complement (C3, C4), urine level and the level of antiDNA antibodies.

\section{Serum sampling}

Venous blood samples for cytokines determinations were collected into pyrogen-free tubes and centrifuged within $20 \mathrm{~min}$ after being allowed to clot at $-4^{\circ} \mathrm{C}$ for $1 \mathrm{~h}$ at $2000 \mathrm{~g}$ for $10 \mathrm{~min}$ at the time of clinical assessment. The serum obtained by us was divided into aliquots and stored at $-25^{\circ} \mathrm{C}$ until assayed. IL-6, TNF- $\alpha$, IL-10 were assayed by specific commercially available, enzyme-linked (ELISA) assay kits (Quantikine, R\&D Systems Inc., USA) in accordance with the manufacturer's protocols.

In each assay the appropriate recombinant human cytokine was used to generate the standard curve. The sensitivities of the assay were: IL- $6,0.3 \mathrm{pg} / \mathrm{ml}$; TNF- $\alpha$, $0.5 \mathrm{pg} / \mathrm{ml}$; IL-10, $7.8 \mathrm{pg} / \mathrm{ml}$. The generation of the superoxide anion radical by peripheral blood granulocytes was determined by the method of Bellavite et

Table 2. Clinical characteristics of 63 patients with SLE

\begin{tabular}{|c|c|c|}
\hline Symptom & $\begin{array}{l}\text { Number } \\
\text { of patients }\end{array}$ & $\%$ \\
\hline Total & 63 & 100 \\
\hline Active & 32 & 50.8 \\
\hline Inactive & 31 & 49.2 \\
\hline Malaise, fever & 30 & 47.6 \\
\hline $\begin{array}{l}\text { Cutaneous and mucous membrane } \\
\text { lesions }\end{array}$ & 55 & 87.3 \\
\hline $\begin{array}{l}\text { Lymphadenopathy, splenomegaly, } \\
\text { hepatomegaly }\end{array}$ & 29 & 43.0 \\
\hline Pneumonitis and/or pleurisy & 8 & 12.7 \\
\hline $\begin{array}{l}\text { Cardiovascular disorders and } \\
\text { Raynaud's phenomenon }\end{array}$ & 49 & 77.8 \\
\hline Gastrointestinal disorders & 9 & 14.3 \\
\hline $\begin{array}{l}\text { Central and/or peripheral nervous } \\
\text { system involvement }\end{array}$ & 43 & 68.3 \\
\hline Arthralgia and/or arthritis & 46 & 73.0 \\
\hline Abnormal blood count, elevated ESR & 51 & 81.0 \\
\hline $\begin{array}{l}\text { Abnormal urinalysis, raised serum } \\
\text { creatinine level }\end{array}$ & 25 & 39.7 \\
\hline ANA $>160$, ds DNA, Sm & 58 & 92.1 \\
\hline
\end{tabular}


$a l .{ }^{14}$ based on evaluation of the degree of reduction of cytochrome $\mathrm{C}$ by superoxide radicals generated by periferal blood granulocytes. Supernatant absorbtion was determined on a Specol 11 spectrophotometer.

\section{Statistical analysis}

Differences in parameters between groups were evaluated with Student's $t$-test. The chi-squared and Fisher's exact tests were used to analyse the relationship between cytokines and generation of $\mathrm{O}_{2}{ }^{-}$at rest and in periods of SLE activity. Internal distribution data were analysed by Student's $t$-test. Correlations were evaluated using Spearman's rank-serum correlation coefficient and linear regression calculated with the least-squares method. Results are presented with $\mathrm{R} 2$ coefficients. Comparisons and correlations were considered significant when $P<0.05$.

\section{Results}

The concentration of IL- 6 , TNF- $\alpha$, IL-10 and the generation of anion radical $\mathrm{O}_{2}{ }^{-}$was significantly higher in patients with SLE and correlated with the activity of the disease (Fig. 1). Table 3 shows the results of measurement of IL- 6 , TNF- $\alpha$, IL-10 and $\mathrm{O}_{2}{ }^{--}$
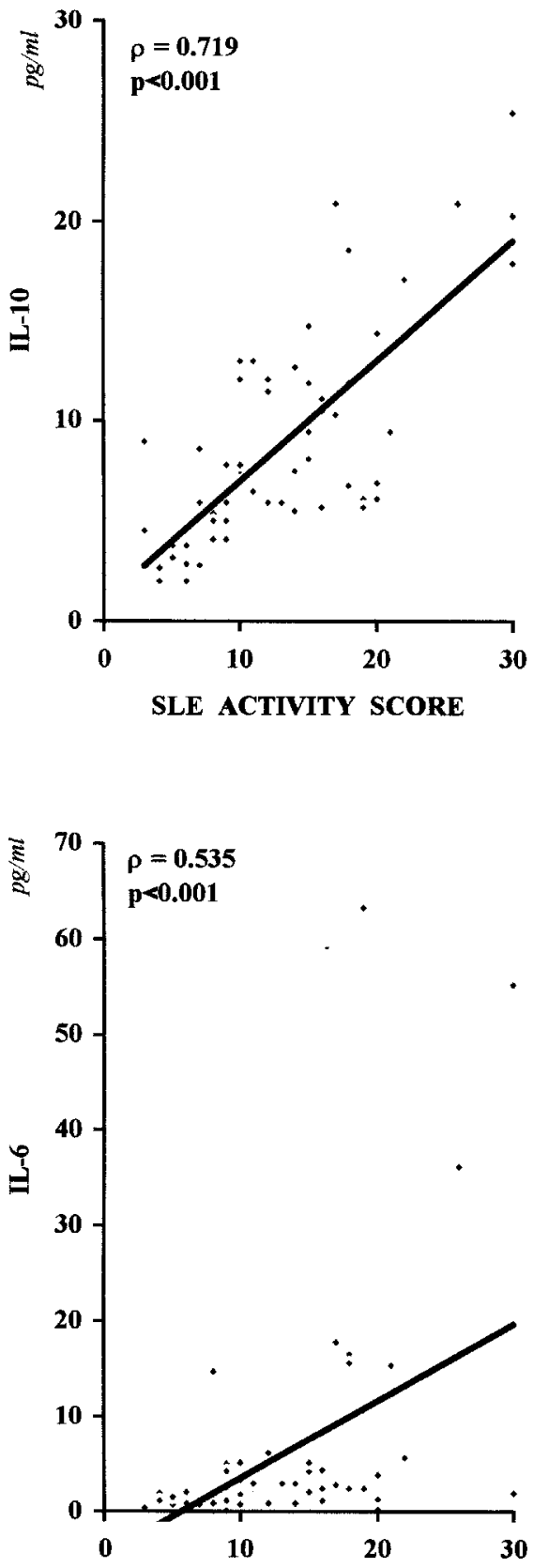

SLE ACTIVITY SCORE
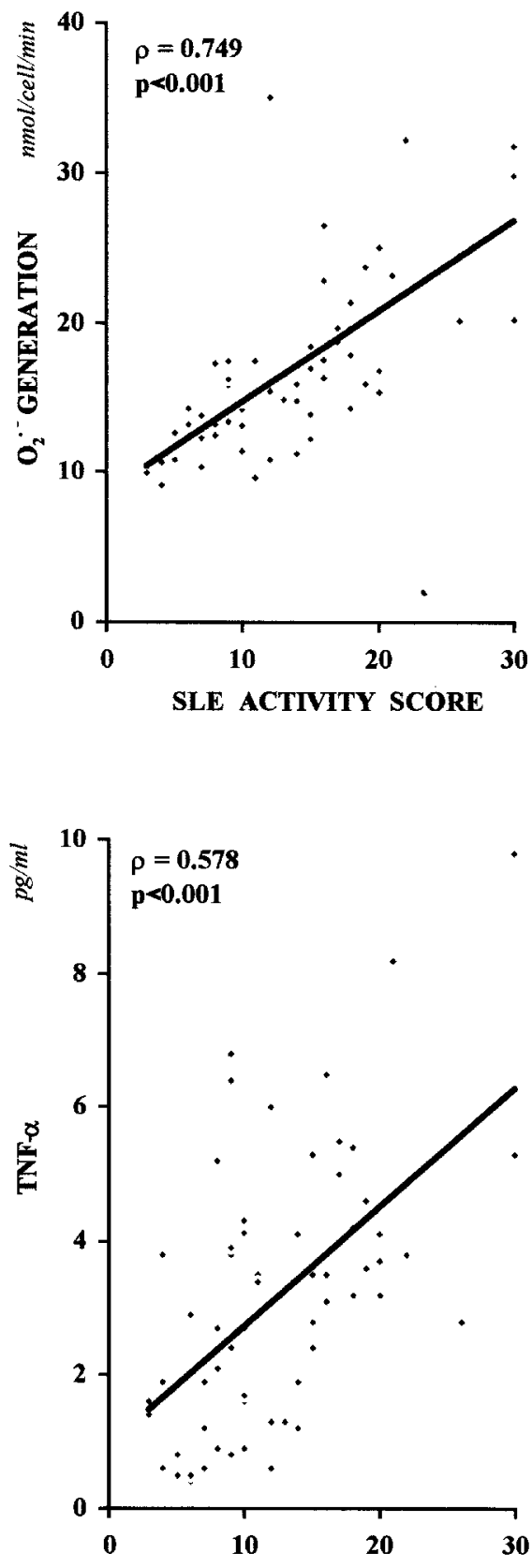

SLE ACTIVITY SCORE

FIG. 1. Correlations between serum level of IL-10, IL-6, TNF- $\alpha$ and generation of $\mathrm{O}_{2}{ }^{--}$with SLE activity. 
Table 3. Serum levels of IL-6, TNF- $\alpha$, IL-10 and generation of $\mathrm{O}_{2}{ }^{--}$in patients with SLE and control group

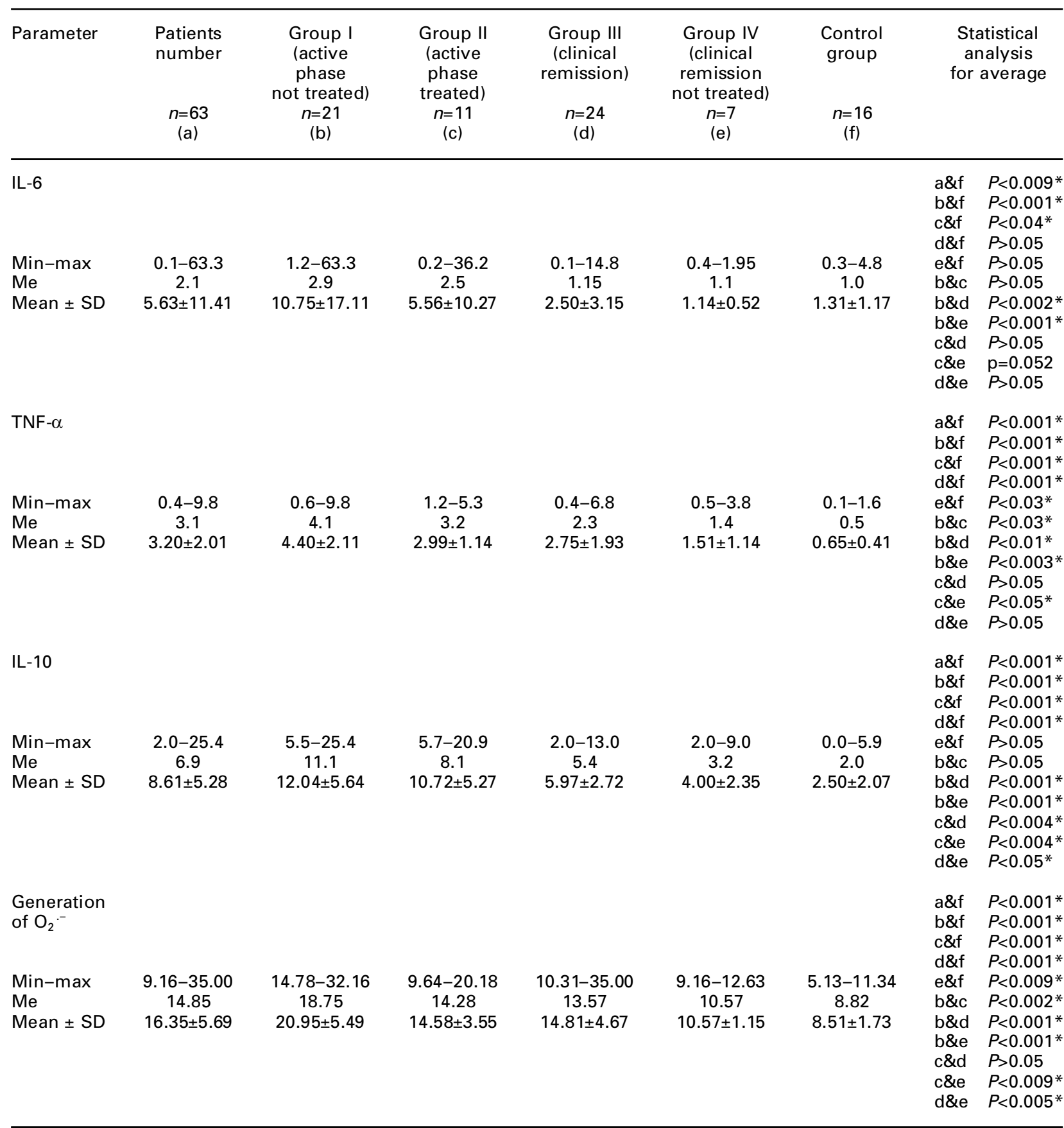

*Differences statistically significant.

in the serum of all patients with SLE, treated and not treated, and 16 normal individuals. In patients with SLE, mean level of IL-6 was $5.63 \mathrm{pg} / \mathrm{ml}$ and was statistically significantly higher in comparison with the control group $(P<0.001)$. The highest level of this cytokine was observed in patients who were at the most active phase of the disease ( $>10$ points in SLAM scale). In our own studies the mean level of TNF- $\alpha$ in patients with SLE was $3.2 \mathrm{pg} / \mathrm{ml}$, while in the control group of normal subjects it was many times smaller, $0.65 \mathrm{pg} / \mathrm{ml}$. The difference in the concentration of this cytokine in all the patients with SLE and in group 1 was statistically significant $(P<0.001)$ and its level correlated with the activity of the disease. The highest level of this cytokine was observed at the most active phase of the disease, before treatment had started. After 7 days of therapy the mean level of TNF- $\alpha$ in these patients decreased significantly and was similar to that observed in patients in the non-active phase $(<10$ points in SLAM scale).

Mean concentration of IL-10 in the studied patients was $8.6 \mathrm{pg} / \mathrm{ml}$ and it was three times higher than in the control group. The level of IL-10 concentration, 
similar to that of IL-6 and TNF- $\alpha$, correlated with the activity of the disease (Fig. 1). Similar to other authors, ${ }^{15}$ we have not found dependence between the concentration of this cytokine and the applied treatment in our group of patients. However, the level of this cytokine was found to correlate with the levels of TNF- $\alpha$, IL-6 (Fig. 2) and the generation of supraoxide anion radical (Fig. 3c). The degree of generation of $\mathrm{O}_{2}{ }^{-}$was significantly higher in the patients and positively correlated with the activity of the disease and applied immunosuppressive treatment (Table 3). Also, a statistically significant positive correlation was seen between the concentration of all studied cytokines and the level of $\mathrm{O}_{2}{ }^{--}$generation (Fig. 3). We have not observed any influence of the applied treatment on IL-6 and IL-10, either in the active or non-active phases. However, the treatment in the active phase statistically significantly decreased the level of TNF- $\alpha$ concentration and degree of $\mathrm{O}_{2}{ }^{--}$generation (Table $3)$.

\section{Discussion}

The pathogenesis of systemic lupus erythematosus is still not fully understood. Recent studies show that some cytokines play a role in the immunological dysregulation in this disease: the literature indicates cytokines of the inflammatory group, i.e. IL- 6 and TNF- $\alpha .{ }^{16,17}$ Elevated levels of IL- 6 have been reported in neoplasms, infections and immunological diseases. ${ }^{18}$ After treatment, the concentration of this

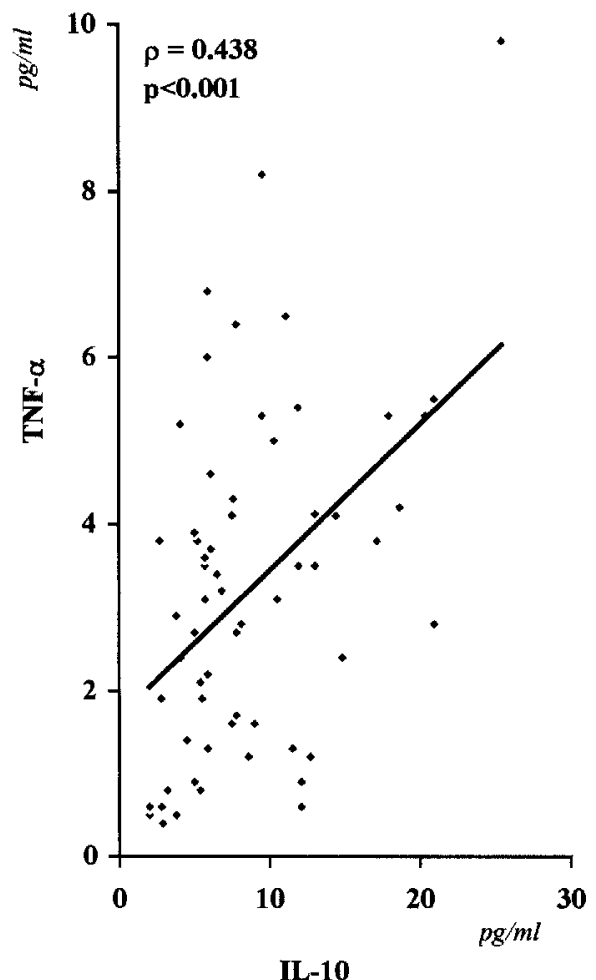

cytokine decreased almost two-fold, which can be explained by the significant influence of glycocorticosteroids on the synthesis of this cytokine. In clinical remission, patients receiving maintenance doses of drugs showed a further decrease in the level of this cytokine. The results obtained in this group were statistically significantly lower than those from patients in a more active phase. In clinical remission of activity (score $<10$ points in SLAM scale) the levels of IL-6 were the lowest and did not differ statistically from those in normal subjects. No statistically significant difference was noted as to the mean concentrations of IL- 6 in treated and non-treated patients in the active phase. This fact may be due to the increased expression of cellular receptors for this cytokine during treatment. ${ }^{19}$ Increased levels of IL-6 in various diseases of the connective tissue were described by other authors. ${ }^{16,17,20,21}$ Spronk et al. ${ }^{22}$ in a group of 71 patients with systemic lupus erythematosus, demonstrated statistically significantly higher levels of this cytokine in those patients who were in the exacerbated phase, and in particular in those cases where changes in the central nervous system were present. Also, in vitro studies confirm the role of IL-6 in the development of SLE, as they showed that lymphocytes $\mathrm{T}$ and $\mathrm{B}$ and monocytes of patients with SLE produce higher amounts of this cytokine compared to normal subjects. ${ }^{16}$

TNF- $\alpha$ has a peculiar effect on human SLE B cells. This cytokine is a growth factor in normal

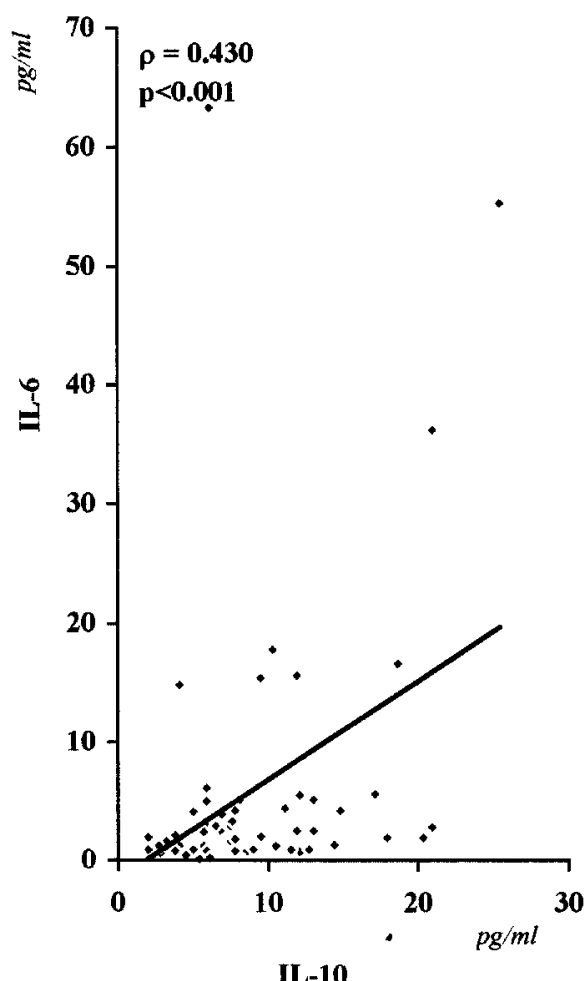

IL-10

FIG. 2. Correlations between IL-10 and TNF- $\alpha$ and between IL-10 and IL-6 serum concentrations in patients with SLE. 


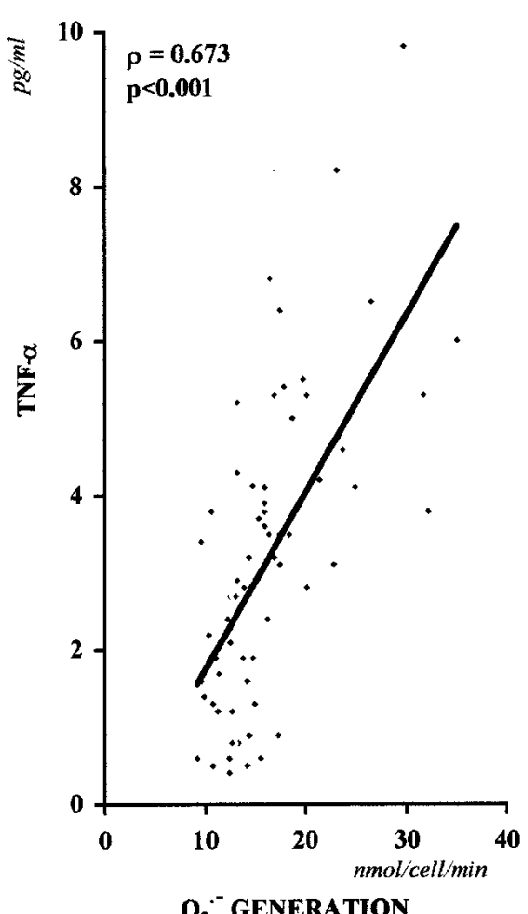

$\mathrm{O}_{2}{ }^{-}$GENERATION
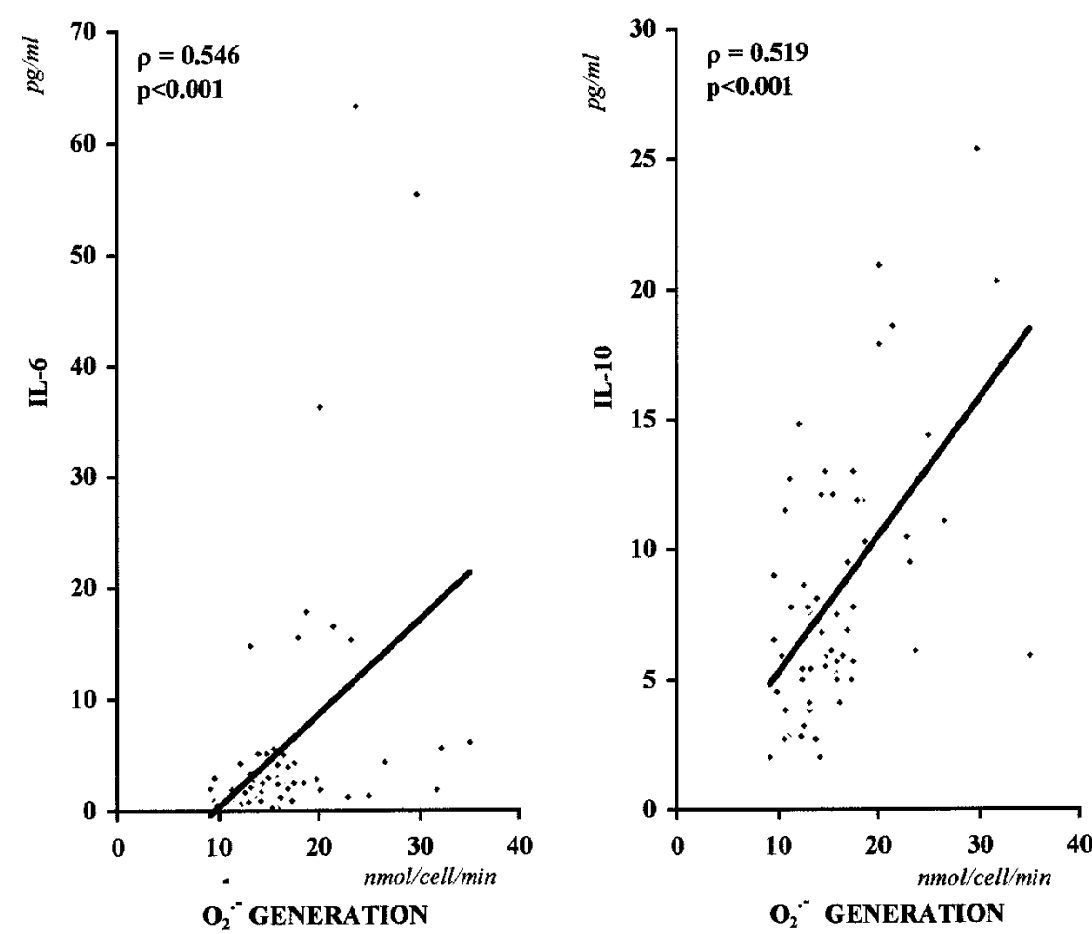

FIG. 3. Correlations between generation of $\mathrm{O}_{2}{ }^{-{ }^{-}}$and TNF- $\alpha, \mathrm{IL}-6, \mathrm{IL}-10$ serum concentrations in patients with SLE.

individuals, but in patients with SLE it inhibits B cell proliferation and spontaneous production of IgM. ${ }^{23}$ Several groups have reported that in vitro production of TNF- $\alpha$ by stimulated PBMCs decreases in human SLE. ${ }^{24}$ At the same time, other investigators have reported that serum levels of TNF- $\alpha$ in SLE are normal or increased. ${ }^{17,25-27}$ The mechanism of TNF$\alpha$ action in SLE is unclear. Although TNF- $\alpha$ protects $\mathrm{NZB} / \mathrm{NZW}$ mice from the renal disease, this therapy does not decrease the titers of anti-DNA antibodies. Moreover, treatment with low-dose TNF- $\alpha$ accelerates renal disease and mortality rate. This phenomenon is probably connected with an immunosuppressive influence of glycocorticosteroids on biosynthesis of TNF- $\alpha{ }^{28}$ Only one report ${ }^{27}$ did not show a correlation between the concentration of this cytokine and the activity of the disease. This may be due to different sensitivity and specificity of the determination method used, e.g. immunoenzymatic or biological method, and the numbers in the groups studied.

Interleukin 10 is a pleiotropic cytokine which may exert immunostimulating and immunosuppressive effects on various types of cells. ${ }^{7}$ IL-10 is a cytokine with an suppressive effect on antigen presentation and $\mathrm{T}$ cell-mediated immune reactions, and is also capable of stimulating polyclonal IgG synthesis. ${ }^{29}$

In vitro studies revealed that IL-10 plays a significant role in the pathogenesis of SLE. Administration of anti-IL-10 antibodies delayed autoimmunisation processes and the formation of renal changes in an animal model on New Zealand mice, NZB/NZW
F1. ${ }^{8}$ Also, in vitro studies showed that stimulated mononuclears from peripheral blood of patients with SLE produce increased amounts of this cytokine. ${ }^{30}$ Both in vivo and in vitro studies revealed that antibodies against IL-10 decrease the production of immunoglobulins, including anti-DNA antibodies. ${ }^{29}$ It is extremely interesting that the dysregulation of IL-10 production, previously identified in SLE patients, is also present in healthy members of families with several cases of SLE, and it may contribute to the immunological abnormalities affecting the relatives of SLE patients. ${ }^{31}$

These observations may confirm not only the importance of this cytokine in the pathogenesis and course of SLE, but also its superior role over other studied proteins which take part in the cytokine cascade. Literature on the possibility of determination of IL-10 in serum of patients with SLE and in healthy individuals is controversial. Houssiau et al. ${ }^{15}$ found detectable concentrations of this cytokine in only $37 \%$ of sick and 3\% of healthy subjects. In our own studies, detectable levels of this protein were found both in the studied group and in the control group. In SLE patients it was also found to correlate with the activity of the disease. It seems that the increased release of this cytokine in patients with SLE is connected with a defect of its inhibitory effect on other cytokines.

In inflammatory diseases, including SLE, phagocyte cells surrounding immunological complexes release high amounts of highly reactive oxygen forms, including supraoxide anion radicals, into the 
extracellular space, ${ }^{32}$ which in turn affect cellular structures, damaging them, or in favourable conditions reacting with iron ions. The direct effect of this oxygen outbreak is damage to cellular membranes. The literature on the level of active oxygen form production, and their role in the pathogenesis of inflammatory diseases is controversial. Ara and $\mathrm{Ali}^{3}{ }^{33}$ in their group of SLE patients, found higher production of free radicals and lipid superoxides compared to normal controls. The authors claim that these radicals may enhance the production of autoantibodies, inflammatory changes in the kidneys and other internal organs. Witt et al. ${ }^{34}$ claim that determination of the level of free radical generation, dependent upon local release of cytokines, may be useful in the evaluation of the severity of pulmonary changes in SLE and systemic sclerosis patients.

Benke et al. ${ }^{35}$ report lack of correlation between the degree of $\mathrm{O}_{2}{ }^{--}$generation and the activity of the disease, although they found increased production in free radicals in patients with SLE. Our own results indicated that while the activity of the disease increases, a significant growth in superoxide radicals generation is observed $P<0.001$. Positive correlation between the level of release of free radicals and levels of studied cytokines indicates that oxygen metabolism plays an important role in the pathogenesis of SLE.

Under physiological conditions IL-10 inhibits both $^{7,31}$ the process of IL- 6 , TNF- $\alpha$ release and the generation of $\mathrm{O}_{2}{ }^{--}$. In the group of the patients examined by us we did not observe this phenomenon. Despite this, there was a statistically significant positive dependence between the concentration of IL-10 and levels of IL- 6 and TNF- $\alpha$ and generation of $\mathrm{O}_{2}{ }^{-}$. This pathological reaction is probably caused by a defect of inhibiting influence of IL-10 in SLE patients on other parameters examined by us.

Oxidative stress functions like a triggering mechanism, leading to an increased production of a number of cytokines, including IL- 6 and TNF- $\alpha$. Lymphokines stimulate polynuclear lymphocytes to phagocytosis and degranulation, and thus increase the generation of free oxygen radicals. Oxidative stress and processes responsible for the production of cytokines interact reciprocally like a vicious circle, and therefore it is difficult to state the reason for this and what the result is. Possibly all these mechanisms together play a significant role in the pathogenesis and course of SLE. Our own results, and the demonstrated correlation between the analysed proteins and the activity of the disease, confirm this hypothesis. As IL-10 seems to play a superior role over the cascade of reaction of release of cytokines and active oxygen forms, which leads to cell destruction, monitoring the concentration of this cytokine may be useful in the evaluation of the activity of the disease.

\section{References}

1. Paty JG, Sienknecht CW, Townes AS, Hanissian AS, Miller JB, Masi AT Impaired cell-mediated immunity in systemic lupus erythematosus (SLE). A controlled study of 23 untreated patients. Am J Med 1975: 59: 769-779.

2. Shoenfeld Y, Mozes E. Pathogenic idiotypes in autoimmunity; lessons from new experimental models of SLE. FASEB J 1990: 4: 2646-2651.

3. Linker-Israeli M. Cytokine abnormalities in human lupus. Clin Immunol Immunopatbol 1992: 63: 10-12.

4. Handwerger BS, Rus V, da Silval, Via CS. The role of cytokines in the immunopathogenesis of lupus. Springer Semin Immunopathol 1994: 16: $153-180$

5. Robak E, Sysa-Jedrzejowska A, Robak T, Stepien H, Wozniacka A, Waszczykowska E. Tumor necrosis factor $\alpha$ (TNF- $\alpha$ ), interleukin-6 (IL-6) and their soluble receptors (sTNF- $\alpha$-Rp55 and sIL-6R) serum levels in systemic lupus erythematodes. Med Inflamm 1996: 5: 435-441.

6. Emilie D, Liorente L, Galanaud P. Interleukin-10, a key cytokine in inflammatory joint disease. Rev Rheum Engl Ed 1995: 62: 229-232.

7. Mosmann TR, Coffiman RL. Properties and functions of interleukin-10. Adv Immunol 1994: 56: 1-26.

8. Ishida H, Hastings R, Karney J, Howard M. Continuous anti-interleukin 10 antibody administration depletes mice of Ly-1 cells but not conventional B cells. J Exp Med 1992: 175: 1213-1216.

9. Antonaccio F, Bassissi P. Free radicals. Chron Dermatol 1994: 4: 1017-1033.

10. Buttke TM, Sandstrom PA. Oxidative stress as a mediator of apoptosis. Immunol Today 1994: 25: 111-121.

11. Knight JA. Diseases related to oxygen derived free radicals. Ann Clin Lab Sci 1995: 25: 11-121

12. Aruoma OI. Nutrition and health aspects of free radicals and antioxidants. Food Chem Toxicol 1994: 32: 671-683

13. Liang MH, Socher SA, Larson MG, Schur PB. Reliability and validity of six systems for the clinical assessment of disease activity in systemic lupus erythematosus. Arthr Rbeum 89: 32: 1107-1118.

14. Bellavite P, Dri P, Della Blamca P et al. The measurement of superoxide anion production by granulocytes in whole blood. A clinical test for the evaluation of phagocyte function and serum opsonic capacity. Eur J Clin Invest 1983: 13: 363-369.

15. Houssiau FA, Lefebre C, Vaden Berghe M, Lambert M, Devogelaer JP Renauld JC. Serum interlaukine 10 titers in systemic lupus erythomatosus reflect disease activity. Lupus 1995: 4: 393-395.

16. Linker-Israeli M, Deans RJ, Wallanne DJ, Prehu J, Ozeri-Chan T, Klimberg JR. Elevated levels of endogenous IL- 6 in systemic lupus erythomatosus. A putative role in pathogenesis. J Immunol 1991: 147: 117-123.

17. Meyer C, Huysen V, Smeeuk RTJ et al. Profiles of cytokines (TNF- $\alpha$ and IL 6 ) and acute phase proietns (CRD and $\alpha 1 \mathrm{AG}$ ) related to the disease course in patients with systemic lupus erythematosus. Lupus 1993: 2: 359-364.

18. Robak T. Biologia interleukiny 6 (IL-6) i jej znaczenie $w$ patogenezie niektÛrych chorÛb. Post Hig Med Dosw 1994: 48: 565-567.

19. Suyer K, de Witt L, Content J. Glucocorticoid upregulation of highaffinity interleukin 6 receptors on human epihtelial cell. Proc Natl Acad Sci USA 1990: 87: 2838-2841.

20. Gabay C, Roux-Lombard P, de Moerloose P, Dayer JM, Visher T, Guerne PA. Absence of correlation between interleukin 6 and $\mathrm{C}$-reactive protein blood levels in systemic lupus erythematosus compared with rheumatoid athritis. J Rbeum 1993: 20: 815-821.

21. Al-Jandai M, Al-Balla S, Al-Dallaan A, Razziuddin S. Cytokine profile in systemic lupus erythematosus, rheumatoid arthritis and other rheumatic diseases. J Clin Immunol 1993: 13: 58-67.

22. Spronk PE, Ter Borg EJ, Limburg PC, Kjllenberg CGM. Plasma concentration of IL-6 in systemic lupus erythematosus and indicator of disease activity. Clin Exp Immunol 1992: 85: 386-391.

23. Mitamura K, Kang H, Tomita Y, Hashimoto H, Sawada S, Horie T. Impaired tumor necrosis factor alpha production and abnormal B cell response to TNF-alpha in patients with systemic lupus erythematosus (SLE). Clin Exp Immunol 1991: 85: 386-391.

24. Malave I, Searles RP, Montano J, Williams RC Jr. Production of tumor necrosis factor/cachectin by peripheral blood mononuclear cells in patients with systemic lupus erythematosus. Int Arch Allergy Appl Immunol 1989: 89: 355-361.

25. Maury CP, Teppo AM. Tumor necrosis factor in the serum of patients with systemic lupus erythematosus. Arthr Rbeum 1989: 32: 146-150.

26. Arai K, Lee F, Miyjama A, Miyatake S, Arai N, Yokota T. Cytokines: coordinators of inflammatory responses. Ann Rev Inc 1990: 59: $783-786$

27. Gordon C, Emery P. Cytokines and the acute phase response in SLE. Lupus 1993: 2: 245-247.

28. Brennan DC, Yui MA, Wuthrich RP, Keley VE. Tumor necrosis factor and IL-1 in New Zealand Black/White mice. J Immunol 1989: 143: $3470-3475$

29. Liorente L, Zou W, Levy L et al. Role of interleukin 10 in B lymphocyte hyperactivity and autoantibody production of human systemic lupus erythomatosus. J Exp Med 1995: 181: 839-844. 
30. Llorente L, Richaud-Patin Y, Wjidens J et al. Spontaneous production of interleukin 10 by B lymphocytes and monocytes in systemic lupus erythomatosus. Eur Cytokine Netw 1993: 4: 421-424.

31. Llorente L, Richaud-Patin Y, Couderc J et al. Dysregulation of IL-10 production in relatives of patients with systemic lupus erythomatosus. Arthritis Rheum, 1997; 40: 1429-1435.

32. Barnes PJ. Reactive oxygen species and airway imflammation. Free Radic Biol Med 1990: 9: 235-243.

33. Ara J, Ali R. Reactive oxygen species modified DNA fragments of varying size are the preferred antigen for human anti-DNA autoantibodies. Immunol Lett 1992: 34: 195-200.

34. Witt C, Neuhans K, Winsel K, BrenkeA, Hiepe F, Volk HD. Bronchoalveolar lavege in patients with systemic lupus erythomatosus: characterisation of cell activity by cytofluorometry, chemiluminescence and differential cell count. Z Erkr Atmungsorgane 1991; 176: 21-29.

35. Benke PJ, Levcowitz H, Pampe J, Tozman E. Scavengers of free radical oxygen effect in the generation of low molecular weight DNA in stimulated lymphocytes from patients with systemic lupus erythomatosus. Metabolism 1990: 39: 1278-1284.

\section{Received 5 January 1999;}

accepted 4 February 1999 


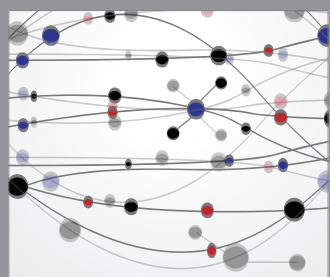

The Scientific World Journal
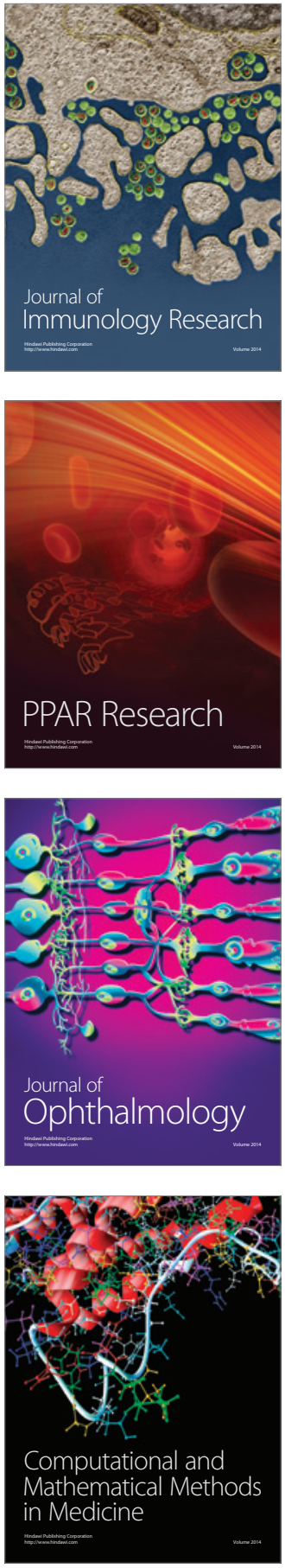

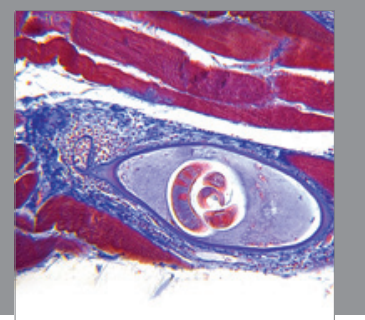

Gastroenterology

Research and Practice
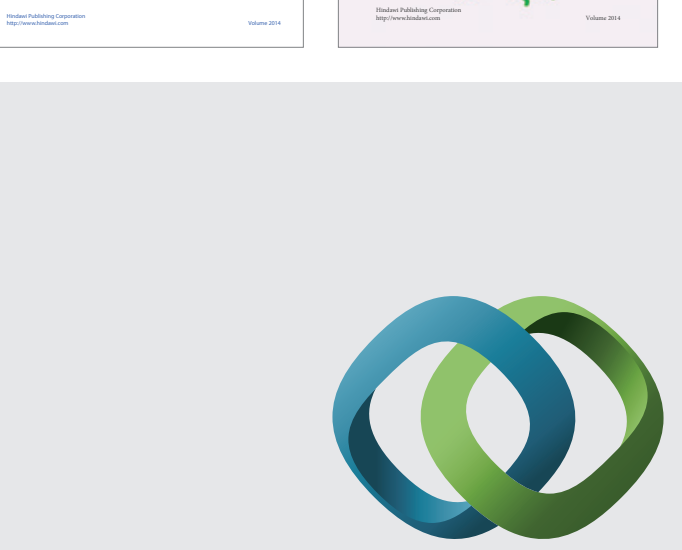

\section{Hindawi}

Submit your manuscripts at

http://www.hindawi.com
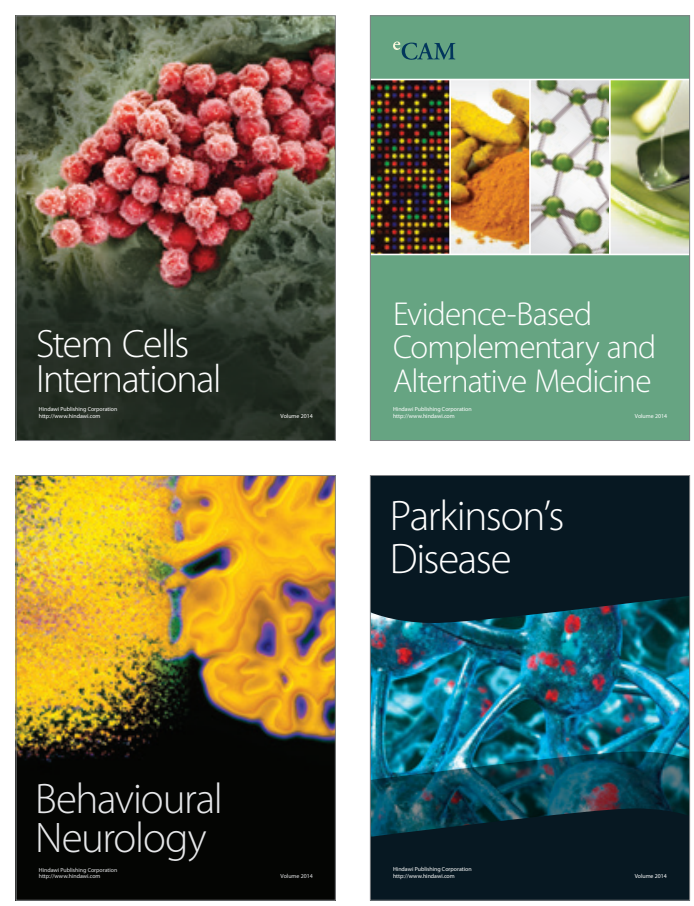

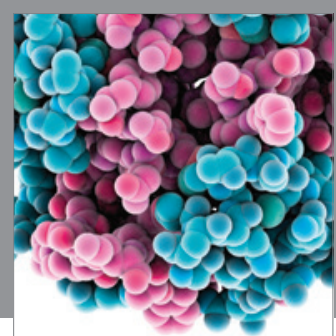

Journal of
Diabetes Research

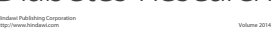

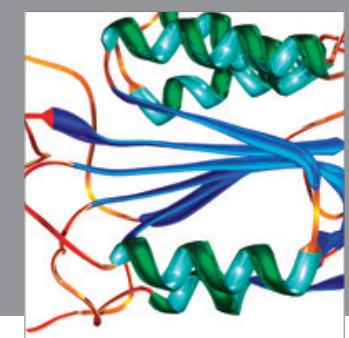

Disease Markers
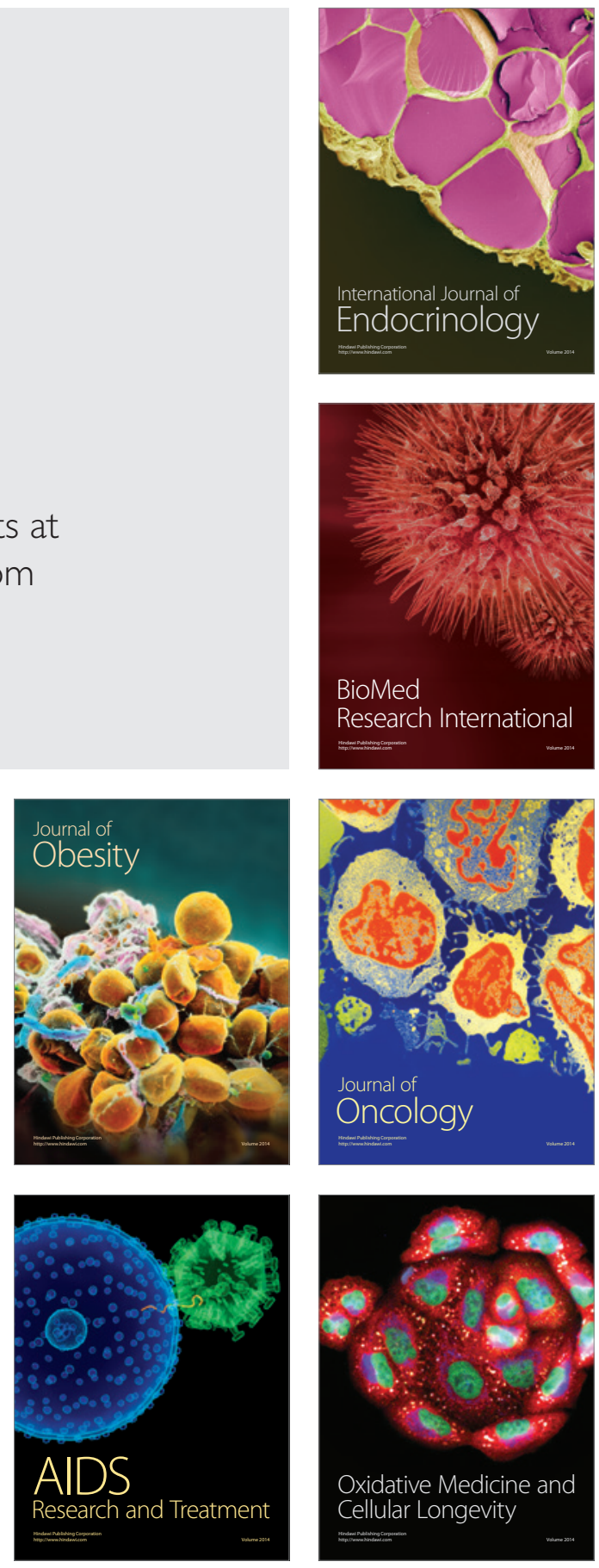